\title{
MEDIA ANTI BULLYING : PEMBIMBINGAN ANAK USIA DINI PADA TAMAN KANAK-KANAK DI KOTA SINGARAJA
}

\author{
Dewi Arum Widhiyanti Metra Putri \\ Jurusan Bimbingan Konseling, Fakultas Ilmu Pendidikan \\ Universitas Pendidikan Ganesha \\ Singaraja, Indonesia \\ e-mail : dewiarumbk@gmail.com
}

\begin{abstract}
Abstrak
Meningkatnya kejadian bullying terhadap anak usia dini menuntut upaya preventif maupun kuratif yang melibatkan pihak-pihak terkait, di antaranya adalah sekolah Taman Kanak-kanak. Upaya yang efektif dapat dilakukan dengan dukungan media sebagai perantara pesan yang ingin disampaikan pada anak usia dini. Permasalahan di lapangan merujuk pada kondisi kurangnya pemahaman guru TK tentang bullying dan pentingnya media bimbingan konseling bermuatan anti bullying untuk anak usia dini. Tujuan yang ingin dicapai melalui kegiatan P2M ini adalah meningkatkan pemahaman dan meningkatkan kemampuan guru TK di Kota Singaraja dalam membuat media bimbingan konseling bermuatan anti bullying untuk anak usia dini. Khalayak sasaran yang dilibatkan dalam kegiatan P2M ini adalah para guru TK di Kota Singaraja, yang berasal dari beberapa gugus. Kegiatan P2M ini dilaksanakan dengan metode ceramah, diskusi, dan workshop, sehingga dapat menghasilkan produk berupa media bimbingan konseling untuk menyampaikan pesan anti bullying bagi anak usia dini. Hasil kegiatan P2M menunjukkan adanya peningkatan pemahaman guru TK tentang perilaku bullying dan peran media BK sebagai sarana menyampaikan pesan yang menaik bagi anak usia dini dan juga pengetahuan tentang pembuatan media untuk menyampaikan pesan anti bullying pada anak usia dini. Pemahaman dan pengetahuan yang semakin bertambah dituangkan dalam pembuatan media. Hasil penilaian dari ahli media BK menunjukkan bahwa secara kuantitatif media yang dihasilkan oleh semua kelompok guru TK berada dalam kriteria sangat baik.
\end{abstract}

Kata Kunci: pelatihan, media bimbingan konseling, anti bullying, anak usia dini.

\section{PENDAHULUAN}

Peristiwa-peristiwa

kekerasan terhadap anak masih terus berlangsung dan bahkan semakin marak di lingkungan sekolah, rumah, maupun di masyarakat. Kekerasan yang terjadi menyangkut banyak perilaku, seperti kekerasan fisik, kekerasan verbal, maupun kekerasan seksual. Jumlah kekerasan yang terjadi Indonesia semakin hari semakin meningkat.

Anak usia dini merupakan bagian dari masyarakat yang rentan terhadap perilaku-perilaku kekerasan. Kerentanan ini dapat dipandang dari dua sisi. Satu sisi menunjukkan bahwa anak usia dini mudah menyerap hal-hal berkaitan dengan kekerasan, seperti halnya mereka menyerap pengetahuan tentang hal-hal yang lain. Bila pihak-pihak yang terkait dengan pendidikan anak usia dini tidak melakukan tindakan-tindakan preventif, besar kemungkinannya akan terbentuk perilaku suka menyakiti dan melakukan kekerasan terhadap teman atau anak yang lain. Sisi yang lain, berkaitan dengan kerentanan anak usia dini yang menjadi korban kekerasan itu sendiri. Kekerasan yang terjadi pada anak usia dini dilakukan oleh teman sebaya dan oleh orang dewasa. Hal ini tentu juga sangat memperihatikan mengingat anak usia dini dipandang sebagai sosok yang lemah dan mudah untuk diintimidasi. Berkaitan dengan kondisi ini, pihak-pihak terkait perlu untuk membekali anak usia dini setidaknya dengan pengetahuan sederhana agar mereka mampu untuk mengenali sejak dini perilaku-perilaku orang lain yang dapat menyakiti dirinya, serta cara untuk menjaga dan mempertahankan dirinya.

Dampak yang dialami oleh korban bullying adalah mengalami berbagai macam gangguan meliputi kesejahteraan psikologis yang rendah (low psychological well-being) dimana korban akan merasa tidak nyaman, takut, rendah diri, tidak 
berharga, penyesuaian sosial yang buruk dimana korban merasa takut kesekolah bahkan tidak mau sekolah, menarik diri dari pergaulan, prestasi akademik yang menurun akibat hilangnya konsentrasi belajar, bahkan yang lebih parah berkeinginan untuk bunuh diri daripada harus menghadapi tekanan-tekanan berupa hinaan dan hukuman.

Pada masa usia dini anak mengalami masa keemasan (the golden years) yang merupakan masa dimana anak mulai peka dan sensitif untuk menerima berbagai rangsangan. Masa peka pada masing - masing anak berbeda, seiring dengan laju pertumbuhan dan perkembangan anak secara individual. Masa peka adalah masa terjadinya kematangan fungsi fisik dan psikis yang siap merespon stimulasi yang diberikan oleh lingkungan. Masa ini juga merupakan masa peletak dasar untuk mengembangkan kemampuan kognitif, motorik, bahasa, sosio emosional, agama, dan moral.

Perkembangan anak usia dini adalah masa - masa kritis yang menjadi fondasi bagi anak untuk menjalani kehidupannya di masa yang akan datang. Hasil penelitian menunjukkan bahwa sebagian dari potensi kecerdasan manusia berkembang dengan pesat pada usia dini. Perkembangan anak pada masa - masa tersebut memberikan dampak terhadap kemampuan intelektual, karakter personal dan kemampuannya bersosialisasi dengan lingkungan. Kesalahan penanganan pada masa perkembangan anak usia dini akan menghambat perkembangan anak yang seharusnya optimal dari segi fisik maupun psikologi.

Sekolah Taman Kanak-Kanak merupakan institusi yang sangat berperan penting dalam kedua hal tersebut di atas. Anak memperoleh pengetahuan dan pengalaman berharga berkaitan dengan pembentukan perilaku anti bullying melalui metode-metode pendidikan yang diimplementasikan oleh guru TK. Salah satu upaya dalam bidang pendidikan untuk mencegah maupun mengatasi masalah bullying sejak dini adalah dengan memberikan bimbingan kepada anak usia dini di lingkungan sekolah itu sendiri. Anak usia dini umumnya akan lebih tertarik jika diperkenalkan pada suatu konsep melalui penggunaan media yang dapat menstimulasi rasa ingin tahu dengan tampilan-tampilan yang menarik. Verbalisasi semata tidak efektif jika diterapkan pada anak usia dini untuk memahami tentang perilaku bullying. Melalui kreatifitas guru, dalam hal ini dalam merancang media bimbingan yang sesuai usia siswa, tujuan untuk mendidik anak usia dini menjadi pribadi anti bullying dapat terujud.

Pada umumnya guru PAUD memiliki kreatifitas yang tinggi dalam menghasilkan suatu media dalam pembelajaran. Namun hal ini masih membutuhkan pendampingan dan pelatihan, terutama dalam menghasilkan media yang bertujuan untuk membimbing anak usia dini agar dapat mengenali perilakuperilaku bullying secara lebih efektif. Dalam merancang suatu media bimbingan bermuatan anti bullying, para guru terlebih dahulu perlu memahami batasan perilaku bullying itu sendiri agar dapat menghasilkan media dengan muatan yang sesuai, terutama bagi anak usia dini. Melalui diskusi dan pelatihan diharapkan para guru memperoleh pengetahuan dan keterampilan yang komprehensif tentang bullying dan media bimbingan yang efektif.

Berdasarkan hasil pengamatan yang dilakukan di Taman Kanak-Kanak di Kota Singaraja, diperoleh hasil bahwa materimateri tentang anti kekerasan pada anak usia dini belum berjalan dengan optimal. Para guru TK tampaknya belum banyak memberikan perhatian terhadap hal ini. Guru TK menjalankan pembelajaran sesuai dengan tema-tema yang telah ditetapkan dalam kurikulum, sedangkan materi tentang anti bullying diselipkan dalam materi-materi yang relevan, misalnya tentang berteman atau keluarga. Sejauh ini belum ada media yang secara khusus dibuat dengan tujuan untuk mengenalkan pada anak sejak dini tentang perilaku-perilaku yang kasar saat berinteraksi dengan teman, terutama yang dipasang di area sekolah.

Guru-guru TK sebenarnya sangat kreatif dalam menghasilkan media pembelajaran. Sedangkan untuk dapat 
menghasilkan media yang bertujuan untuk membimbing siswa dalam pembentukan perilaku masih belum ada. Para guru menyadari bahwa penting untuk dapat membimbing anak usia dini dalam berperilaku, sebab mereka menyadari bahwa fondasi perilaku dan sikap anak di kemudian hari ditentukan saat usia mereka masih muda.

Pengetahuan yang dimiliki oleh guru TK tentang bullying juga dirasakan masih terbatas. Mereka banyak mendengar dan membaca kasus-kasus bullying melalui media dan turut merasa prihatin. Namun mereka sendiri belum menyadari apakah mungkin di sekitar anak di lingkungan sekolah juga berisiko terjadi bullying, atau bahkan ada anak-anak yang membutuhkan bimbingan karena tampaknya sering menyakiti temannya yang lain. Dalam Bahasa Indonesia, kata bully berarti penggertak, orang yang mengganggu orang yang lemah (Wiyani, 2012: 12).

Selanjutnya menurut Olweus (dalam Geldard, -) mengemukakan bahwa Bullying dapat didefinisikan sebagai sebuah tindakan atau perilaku agresif yang disengaja, yang dilakukan oleh sekelompok orang atau seseorang secara berulang-ulang dari waktu kewaktu terhadap seorang korban yang tidak dapat mempertahankan dirinya dengan mudah. Coloroso (2007) mengartikan bullying sebagai suatu penindasan.

Media bimbingan konseling adalah segala sesuatu yang menyalurkan pesan bimbingan konseling dari dua unsur yaitu Perangkat lunak (software) merupakan informasi bimbingan konseling yang disampaikan pada konseli, sedangkan perangkat keras (hadware) adalah peralatan yang menyajikan pesan bimbingan konseling (Nursalim, 2010: 7). Berdasarkan pendapat diatas, dapat disimpulkan bahwa media bimbingan konseling merupakan wadah dari pesan, materi yang ingin disampaikan adalah pesan bimbingan konseling, serta tujuan yang ingin dicapai adalah mencapai perkembangan siswa yang maksimal.

Secara umum media mempunyai kegunaan sebagai berikut: (1) memperjelas pesan agar tidak terlalu verbalistis; (2) mengatasi keterbatasan ruang, waktu, tenaga, dan daya indera; (3) menimbulkan gairah/minat siswa, interaksi lebih langsung antara siswa dengan guru; (4) memberikan rangsangan yang sama, mempersamakan pengalaman, dan menimbulkan persepsi yang sama; (5) proses layanan bimbingan dapat lebih menarik; (6) proses layanan bimbingan menjadi lebih interaktif; (7) kualitas layanan dapat ditingkatkan; dan (8) meningkatkan sikap positif siswa terhadap materi layanan.

Hal yang juga mendukung urgensi dari kegiatan ini adalah adanya beberapa kejadian yang ditemukan di lokasi, tepatnya di sekolah Taman Kanak-kanak yang pernah dikunjungi oleh pelaksana kegiatan P2M. Perilaku agresif yang ditunjukkan oleh satu atau dua orang siswa TK telah menjurus pada bentuk kekerasan yang melukai teman di sekolahnya. Perilaku yang tampak seperti menyiram temannya dengan pasir di bagian wajah sambil mendorong atau menertawakan. Perilaku lainnya adalah menggigit lengan teman hingga terluka dan berdarah karena keinginannya tidak terpenuhi. Perilaku-perilaku tersebut memang tidak secara terus menerus di lakukan oleh siswa. Tentunya hal ini juga penting untuk menjadi perhatian karena jika anak belum memperoleh pendekatan yang tepat maka muncul risiko akan menunjukkan perilaku bullying terhadap teman atau di lingkungannya. berikut:

Tujuan kegiatan adalah sebagai

1. Meningkatkan pemahaman guru TK di Kota Singaraja mengenai pentingnya media BK bermuatan anti bullying pada anak usia dini di lingkungan sekolah.

2. Meningkatkan kemampuan guru TK di Kota Singaraja untuk merancang media BK anti bullying untuk anak usia dini. berikut:

Manfaat kegiatan adalah sebagai

1. Bagi guru TK, yaitu meningkatkan pemahaman tentang pentingnya media BK bermuatan anti bullying dan meningkatkan keterampilan merancang media bimbingan bermuatan anti bullying untuk anak usia dini. 
2. Bermanfaat untuk meningkatkan kualitas dan kuantitas kolaborasi antara universitas dan sekolah dalam upaya pelaksanaan program anti bullying.

\section{METODE PELAKSANAAN}

Anak usia dini adalah kelompok individu yang berada pada usia yang rentan terhadap tindakan bullying. Kerentanan yang dimaksud adalah bahwa anak usia dini rentan sebagai korban bullying ataupun sebagai pelaku dari bullying itu sendiri. Kedua hal ini dapat disebabkan karena anak belum memiliki pemahaman yang cukup tentang perilaku bullying yang dapat merugikan orang lain dan dirinya sendiri. Karakteristik anak usia dini menyebabkan perlu adanya bimbingan dari semua pihak yang berperan dalam perkembangan anak. Salah satu pihak yang berperan penting adalah guru dan lingkungan di sekolah. Guru dapat memberikan bimbingan kepada anak usia dini di sekolah dengan menggunakan metode atau media yang tepat bagi anak agar mudah dipahami dan dipraktikkan. Kondisi ini menuntut guru agar dapat menghasilkan media bimbingan yang sesuai dengan karakteristik anak usia dini.

Guru-guru TK sejauh ini menunjukkan kreativitas yang tinggi dalam membuat media pembelajaran bagi siswanya. Namun belum tampak pemanfaatan media sebagai sarana bimbingan bagi anak usia dini khususnya untuk memperkenalkan konsep anti bullying. Isi dari media bimbingan yang bermuatan anti bullying dapat dikreasikan sedemikian rupa agar anak usia dini dapat memperoleh pemahaman dalam bahasa yang mereka mengerti. Pelatihan pembuatan media bimbingan untuk anak usia dini yang bermuatan anti bullying perlu dilakukan agar guru TK dapat menghasilkan media yang sesuai dengan karakteristik anak usia dini sekaligus dapat menyampaikan pesan secara efektif pada anak.

Sesuai dengan pendahuluan dan analisis situasi, maka khalayak sasaran strategis kegiatan P2M ini adalah guruguru TK di Kota Singaraja yang teridentifikasi masih belum memiliki pemahaman dan kemampuan yang optimal untuk merancang media bimbingan bermuatan anti bullying untuk anak usia dini di sekolahnya masingmasing. Khalayak sasaran kegiatan ini adalah para guru TK di Kota Singaraja. Pada saat kegiatan beberapa sekolah yang mengirimkan perwakilan gurunya adalah TK Negeri Pembina Singaraja, TK Trisula, TK Ceria Asih, TK Dharma Suda, TK Kumara Bhuana, TK Aisyiyah, TK At Thooriq, TK Kuncup Harapan, dan TK Nurul Huda.

Kegiatan P2M ini diselenggarakan di TK Negeri Pembina Singaraja dengan melibatkan guru-guru TK di Kota Singaraja. Kegiatan P2M ini juga mengundang pihak-pihak terkait, yaitu perwakilan dari LPM Undiksha, para kepala sekolah TK di Kota Singaraja, ketua gugus TK di Kota Singaraja, dosen Jurusan BK, dan pimpinan Jurusan BK.

Metode yang digunakan untuk mencapai tujuan yang telah dirumuskan dalam P2M ini adalah metode ceramah, diskusi dan juga pelatihan (implementasi prosedur perancangan media) yang dilaksanakan dalam bentuk seminar dan workshop. Gabungan metode tersebut diharapkan mampu meningkatkan pemahaman guru-guru TK tentang media bimbingan bermuatan bullying dan bagaimana merancang media tersebut agar sesuai bagi anak usia dini.

Keberhasilan kegiatan pelatihan ini akan dievaluasi melalui:

1. Evaluasi proses: dilihat dari aktifitas peserta mengikuti kegiatan pelatihan

2. Evaluasi hasil/produk: dilihat dari produk yang dihasilkan dalam workshop, yaitu media bimbingan bermuatan anti bullying yang sesuai untuk anak usia dini.

\section{HASIL DAN PEMBAHASAN}

Produk yang dihasilkan dalam kegiatan ini adalah media bimbingan dan konseling bermuatan anti bullying untuk anak usai dini. Media yang dihasilkan oleh lima kelompok guru TK dinilai dengan menggunakan instrument berupa lembar validasi produk berupa angket. Indikator yang digunakan dalam menilai media BK yang dihasilkan dalam kegiatan ini adalah 
(1) kesesuaian isi/materi yang dicantumkan pada media, (2) kemenarikan tampilan media, (3) kualitas bahan yang digunakan, (4) ketepatan ukuran media, (5) ketepatan ukuran gambar, (6) ketepatan ukuran tulisan, (7) kejelasan gambar pada media untuk menyampaikan pesan, (8) kemudahan penggunaan media. Penilaian setiap indikator menggunakan penilaian skala lima dan nilai total dibagi Skor maksimal ideal dan dikalikan seratus persen. Nilai yang diperoleh dikonversi ke Pedoman Konversi dengan menggunakan Pedoman Acuan Penilaian (PAP) Skala Lima.

Berikut adalah hasil penilaian terhadap produk media BK bermuatan anti bullying untuk anak usia dini yang dihasilkan oleh para guru.

Tabel 1. Hasil Penilaian Media BK Bermuatan Anti Bullying Untuk Anak Usia Dini.

\begin{tabular}{cccc}
\hline Kelompok & Jenis Media & Nilai Rata-rata & Kriteria \\
\hline 1 & Papan bimbingan & 35,5 & Sangat baik \\
\hline 2 & Papan bimbingan & 37,5 & Sangat baik \\
\hline 3 & Papan bimbingan & 34 & Sangat baik \\
\hline 4 & Papan bimbingan & 38 & Sangat baik \\
\hline 5 & Wayang & 34,5 & Sangat baik \\
\hline
\end{tabular}

Berdasarkan Tabel 1. diketahui bahwa berdasarkan penilaian TIM P2M semua media bimbingan yang dihasilkan selama workshop memperoleh nilai di atas rata-rata dan termasuk dalam kriteria sangat baik berdasarkan hasil penilaian dari dua orang ahli media BK.

Secara kualitatif terdapat beberapa hal yang dapat menjadi masukan bagi pengembangan media BK bermuatan anti bullying untuk anak usia dini. Saran-saran tersebut, yaitu sebagai berikut: (1) guru dapat mencari gambar-gambar yang menarik dari internet untuk menambah referensi agar tampilan media dapat lebih menarik, (2) pencantuman tulisan atau kalimat yang dapat mudah dibaca dan dimengerti oleh anak usia Taman Kanakkanak, (3) penggunaan lem yang lebih banyak agar gambar dapat melekat lebih kuat, (4) penggunaan tangkai wayang yang lebih kuat atau digandakan, (5) pesan yang disampaikan dapat lebih variatif dan memungkinkan untuk mengganti gambarnya secara kontinu.

Pelaksanaan kegiatan Pengabdian Pada Masyarakat yang dilaksanakan dengan melibatkan para guru TK di Kota Singaraja dinilai mampu untuk menambah pengetahuan dan juga keterampilan dalam menghasilkan media BK bermuatan anti bullying yang sesuai untuk anak usia dini. Kegiatan diawali dengan ceramah tentang perilaku bullying dan media BK yang berfungsi untuk memberikan informasi bagi anak usia dini tentang perilaku bullying dan perilaku yang sebaiknya ditanamkan pada anak. Pengetahuan ini kemudian diimplementasikan saat kegiatan workshop hari kedua, di mana para guru merancang dan membuat media BK yang sesuai dengan kriteria media bimbingan yang baik.

Kegiatan P2M kali ini menghasilkan beberapa media BK yang dihasilkan oleh lima kelompok yang anggotanya terdiri atas guru TK dan mahasiswa Jurusan BK. Setiap kelompok terdiri atas guru-guru yang berasal dari sekolah yang berbedabeda sehingga kerjasama dan kekompakan dapat ditumbuhkan antar sekolah yang memiliki kondisi dan kebiasaan yang berbeda. Empat kelompok menghasilkan media berupa papan bimbingan dan satu kelompok menghasilkan media wayang. Secara umum, media BK yang dihasilkan oleh setiap kelompok sangat menarik dan 
memenuhi kriteria media BK yang berkualitas sangat baik.

Peserta kegiatan P2M ini menunjukkan antusiasme yang tinggi ditunjukkan dengan kehadiran peserta yang lengkap pada hari pertama dan kedua pelaksanaan kegiatan, antusiasme saat diskusi atau tanya jawab, serta kreativitas dan keseriusan yang ditunjukkan saat mengikuti workshop. Keterampilan guru TK untuk menghasilkan media pembelajaran yang selama ini sedemikian terlatih sangat membantu dan mempermudah peserta untuk menghasilkan media yang menarik dan tepat sasaran. Dukungan dari kepala sekolah juga sangat berperan dalam kelancaran dan keberhasilan kegiatan P2M kali ini.

\section{KESIMPULAN DAN SARAN}

Kegiatan P2M penerapan iptek yang dilaksanakan dengan melibatkan guru TK di Kota Singaraja kali ini menunjukkan hasil bahwa terjadi peningkatan pengetahuan dan keterampilan dari peserta untuk dapat menghasilkan media BK bermuatan anti bullying yang sesuai bagi anak usia dini. Secara kuantitatif dan kualitatif produk media yang dihasilkan sudah cukup baik dengan mengacu pada kriteria-kriteria media bimbingan dan konseling yang telah divalidasi oleh ahli. Terdapat beberapa saran yang diberikan oleh ahli dan tim pelaksana P2M dari produk media yang dihasilkan dan menjadi acuan dalam membuat media oleh peserta di sekolahnya masingmasing.

Beberapa saran yang diajukan terkait dengan kegiatan P2M yang telah dilaksanakan adalah sebagai berikut: (1) Para guru TK yang mengikuti kegiatan P2M ini diharapkan dapat terus berlatih dalam menghasilkan media bimbingan konseling sesuai dengan kebutuhan di sekolahnya masing-masing, (2) Para guru TK diharapkan dapat lebih banyak memanfaatkan teknologi untuk memperoleh referensi dalam menghasilkan media bimbingan konseling yang berkualitas dan tepat sasaran, (3) Para guru TK diharapkan dapat mensosialisasikan pengetahuan dan keterampilannya kepada guru-guru lainnya agar dapat memberikan manfaat yang lebih luas.

\section{DAFTAR PUSTAKA}

Priyatna, Andi. 2010. Lets End Bullying: Memahami, Mencegah, dan Mengatasi Bullying, Jakarta: Elex Media Komputindo.

Coloroso, Barbara. 2007. Stop Bullying, Jakarta: Serambi IImu Semesta.

Nursalim, M. 2010. Media Bimbingan Konseling. Surabaya: Unesa University Press.

Wiyani, N.A. 2012. Save Our Children From School Bullying, Jogjakarta: Ar- Ruzz Media. 